\title{
Nitrogen metabolism in coffee plants in response to nitrogen supply by fertigation
}

\author{
Ana Paula Neto • José Laércio Favarin • André Rodrigues dos Reis • \\ Tiago Tezotto $\cdot$ Rodrigo Estevam Munhoz de Almeida • \\ José Lavres Junior • Luiz Antonio Gallo
}

Received: 9 June 2014/ Accepted: 26 November 2014/Published online: 20 December 2014

(C) Brazilian Society of Plant Physiology 2014

\begin{abstract}
Coffee plants require high application rates of nitrogen $(\mathrm{N})$ to produce coffee beans. However, information regarding plant $\mathrm{N}$ uptake and assimilation under intensive high-technology cultivation systems is scarce, a situation which restrains the maximizing productivity with minimal $\mathrm{N}$ rates. The aim of this study was to evaluate $\mathrm{N}$ assimilation enzymes such as nitrate reductase (EC 1.6.6.1), glutamine synthetase (EC 6.3.1.2), urease (EC 3.5.1.5), and $\mathrm{N}$ compounds of coffee plants during a phenological cycle in response to $\mathrm{N}$ applied by fertigation. Our study was carried out with 7-year-old trees of Coffea arabica L., under a center pivot sprinkler irrigation and fertigation system, with five $\mathrm{N}$ rates $\left(0,200,400,600\right.$, and $\left.800 \mathrm{~kg} \mathrm{ha}^{-1}\right)$ applied to the coffee field. The results of the present study suggest that both $\mathrm{N}$ metabolism enzymes, and the
\end{abstract}

A. P. Neto · J. L. Favarin - T. Tezotto

Laboratório Multiusuário em Produção Vegetal, Departamento de Produção Vegetal, Escola Superior de Agricultura 'Luiz de Queiroz', Universidade de São Paulo, Piracicaba, SP CEP 13418-900, Brazil

A. R. dos Reis

Engenharia de Biossistemas, Universidade Estadual Paulista 'Julio de Mesquita Filho', Tupã,

SP CEP 17602-496, Brazil

T. Tezotto $(\bowtie)$

Crop Science Department, Luiz de Queiroz College of Agriculture, University of São Paulo, Av. Páduas Dias, 11, CP 9, Piracicaba, SP CEP: 13418-900, Brazil e-mail: tiagotezotto@gmail.com; tiago.tezotto@usp.br content of nitrate and ammonium in coffee were directly related to the phenological cycle. The $\mathrm{N}$ fertigation rates are correlated with the $\mathrm{N}$ and amino acid contente. Nitrate reductase and urease showed higher activities before anthesis and during grain filling. Glutamine synthetase showed highest activities during rapid grain expansion. The data also indicate that there is merit in gaining greater understanding of $\mathrm{N}$ metabolism in coffee plants grown under high-intensive systems. There is therefore merit in conducting further research on how monitoring the $\mathrm{N}$ assimilation enzymes might be used to improve fertilizer management of coffee in commercial orchards.

Keywords Coffea arabica - Glutamine synthetase . Nitrate reductase $\cdot$ Urease

\author{
R. E. M. de Almeida \\ Embrapa Pesca e Aquicultura, Palmas, \\ TO CEP 77020-020, Brazil \\ J. Lavres Junior \\ Centro de Energia Nuclear na Agricultura, Universidade \\ de São Paulo, Piracicaba, SP CEP 13418-900, Brazil
}
L. A. Gallo
Departamento de Ciências Biológicas, Escola Superior de Agricultura 'Luiz de Queiroz', Universidade de São Paulo, Piracicaba, SP CEP 13418-900, Brazil 


\section{Introduction}

In the last decade coffee (Coffea arabica L.) cultivation has expanded to marginal areas such as Western Bahia State, Brazil, with an irregular rainfall distribution throughout the year. This region presents a smooth topography, which facilitates the adoption of high technology such as center pivot sprinkler irrigation (Neto et al. 2011). Coffee plants of this region have high rates of vegetative growth and productivity index averaged 2,400-3,600 $\mathrm{kg} \mathrm{ha}^{-1}$ per year (CONAB 2010; Neto et al. 2011) and 600-800 $\mathrm{kg} \mathrm{ha}^{-1} \mathrm{~N}$ as urea applied to maintain this productivity. The high vegetative growth and yield occur primarily because of the greater number of sunlight hours due to less cloudiness, and average temperatures around $20{ }^{\circ} \mathrm{C}$ in the months of autumn and winter. This temperature above that of traditional cultivation regions (Neto et al. 2011), might provide better physiological conditions for growth.

$\mathrm{N}$ is the nutrient of greatest demand by coffee plants. $\mathrm{N}$ assimilation is a vital process for plant growth, being directly responsible for crop biomass production and grain yield (Fenilli et al. 2007; Reis et al. 2011). Regarding the total $\mathrm{N}$ absorbed by coffee plants, nitrate is the predominant form transported in xylem sap, representing more than $50 \%$ of the total N (Mazzafera and Gonçalves 1999) that is reduced to nitrite by nitrate reductase (Wray and Fido 1990).

However, the quantitative contribution of nitrate sources as fertilizer is low and urea is the most widely used nitrogen fertilizer in agriculture (http://faostat. fao.org). Although urea is converted in part to ammonium and nitrate in the soil, little is known about urea uptake and metabolism in plants (Witte 2011). In addition, significant amounts of plant $\mathrm{N}$ flow through urea, which is derived from arginine degradation by arginase (Polacco et al. 2013). The $\mathrm{N}$ present in urea is unavailable to the plants unless hydrolyzed by the tissue-ubiquitous urease (Polacco et al. 1985). The $\mathrm{N}$ product of urease activity-ammonia-is incorporated into organic compounds mainly by glutamine synthetase (Sirko and Brodzik 2000). Therefore, nitrate reductase and glutamine synthetase activities might represent the rate-limiting step in $\mathrm{N}$ assimilation, as they can be used as a marker for the capacity of roots and shoots to assimilate external $\mathrm{N}$ in coffee plants (Reis et al. 2009). Due to the importance of $\mathrm{N}$ as the main nutrient for plants and its regulatory role in plant metabolism, it has been suggested that nitrate reductase activity is related to plant productivity and/or to a significant response to $\mathrm{N}$ fertilization (Malavolta et al. 2004; Reis et al. 2007, 2009).

Official bulletins of fertilization recommend about $400 \mathrm{~kg} \mathrm{ha}^{-1}$ of N per year (Raij et al. 1996) split into twice or four applications. Coffee growers in the western part of Bahia State, Brazil, generally apply high $\mathrm{N}$ at rates between 600 and $800 \mathrm{~kg} \mathrm{ha}^{-1}$ as urea, distributed as much as 26 times during coffee cycle, without a clear knowledge on the impact on coffee plant physiology. In fact, because of rapid vegetative growth and high productivity, several coffee farmers in Minas Gerais and Bahia State, Brazil, have been applying excessive $\mathrm{N}$-urea fertilizer in an attempt to prevent $\mathrm{N}$ deficiency, thus further reducing crop efficiency. Although there is considerable knowledge available on $\mathrm{N}$ fertilization in coffee, the effects of such high rates on coffee physiology are not known. Moreover, the application of high $\mathrm{N}$ rates can increase losses by lixiviation, volatilization, and denitrification or erosion (Peoples et al. 1995). These losses can be minimized by synchronizing the fertilizer application with the plant's physiological demand (Matson et al. 1998; Panek et al. 2000; Matějková et al. 2010).

The aim of our work was to evaluate the changes in the $\mathrm{N}$ metabolic (assimilatory) enzymes as well as the nutritional status of $\mathrm{N}$ in coffee plants due to high $\mathrm{N}$-urea supplied by fertigation during phenological phases.

\section{Materials and methods}

A field experiment was conducted between August 2008 and July 2009 on the Morena Farm located in Luiz Eduardo Magalhães, Bahia State, Brazil, $11^{\circ} 46^{\prime} 00^{\prime \prime} \mathrm{S}$ and $45^{\circ} 43^{\prime} 32 \mathrm{~W}$, at an altitude of $740 \mathrm{~m}$, with an average annual temperature of $23^{\circ} \mathrm{C}$ and rainfall of $1,500 \mathrm{~mm}$. The time course of monthly mean precipitation and air temperature from August 2008 to July 2009 is illustrated in Fig. 1. Plants of Coffea arabica L. var. Catuaí. Vermelho H-2077-144 with seven years-old and grown with spacing of $3.8 \times 0.5 \mathrm{~m}(5,263$ plants per hectare $)$ were used in the study. Coffee trees were arranged circularly, with a central pivot for directed irrigation and fertirrigation. The region's climate is classified as Aw or 


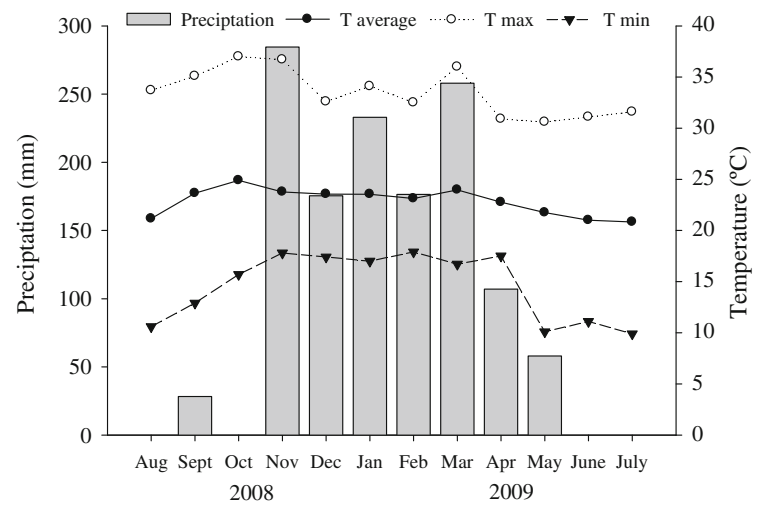

Fig. 1 Time course of monthly mean precipitation (mm) and air temperature $\left({ }^{\circ} \mathrm{C}\right)$ from August 2008 to July 2009

savanna on the Köppen scale, with hot and wet summers and cool and generally dry winters. The soil is classified as Oxisol (Red-Yellow Latosol), with medium texture. Soil sample were collected at depth of 0-200 $\mathrm{mm}$ and the following parameters were determined: $\mathrm{pH} 4.7$ (1:2.5 soil:0.01 mol $\mathrm{CaCl}_{2}$ ); organic matter $(\mathrm{OM})$ : $25 \mathrm{~g} \mathrm{dm}^{-3}$ (colorimetric method); sulfur (S): $10 \mathrm{mg} \mathrm{dm}^{-3}$ (turbidimetric method); phosphorus (P): $114 \mathrm{~g} \mathrm{dm}^{-3}$, potassium $\left(\mathrm{K}^{+}\right): 2 \mathrm{mmol}_{\mathrm{c}} \mathrm{dm}^{-3}$, calcium $\left(\mathrm{Ca}^{2+}\right): 23 \mathrm{mmol}_{\mathrm{c}} \mathrm{dm}^{-3}$ and magnesium $\left(\mathrm{Mg}^{2+}\right): 9$ $\mathrm{mmol}_{\mathrm{c}} \mathrm{dm}^{-3}$ (ion exchange resin); aluminum (Al): 3 $\mathrm{mmol}_{\mathrm{c}} \mathrm{dm}^{-3}$ (titrimetric method); potential acidity $(\mathrm{H}+\mathrm{Al}): 31 \mathrm{mmol}_{\mathrm{c}} \mathrm{dm}^{-3}$ (pH SMP method); cation exchange capacity (CEC): $65 \mathrm{mmol}_{\mathrm{c}} \mathrm{dm}^{-3}$; base saturation (V), $52 \%$; boron (B): $0.74 \mathrm{mg} \mathrm{dm}^{-3}$ (hot water); copper $\left(\mathrm{Cu}^{2+}\right)$ : $9.6 \mathrm{mg} \mathrm{dm}{ }^{-3}$, iron $\left(\mathrm{Fe}^{2+}\right)$ : $82 \mathrm{mg} \mathrm{dm}^{-3}$, manganese $\left(\mathrm{Mn}^{2+}\right): 3.1 \mathrm{mg} \mathrm{dm}^{-3}$, and zinc $\left(\mathrm{Zn}^{2+}\right)$ : $3.6 \mathrm{mg} \mathrm{dm}^{-3}$ (2:1 soil:DTPA-TEA solution; 0.005 mol diethylenetriamine acid $+0.1 \mathrm{~mol}$ triethanolamine $+0.01 \mathrm{~mol} \mathrm{CaCl}_{2}$ ).

Fertigation is performed on the farm site using lowenergy precision application (LEPA), in which water plus fertilizers are sprinkled locally on the rows of plants. Coffee trees were irrigated throughout the year, except during harvest, with application of an average of 3-4 $\mathrm{mm}$ per day on alternate days. The LEPA sprinkler was closed during fertigation with $\mathrm{N}$-urea in the experimental plots. The application of $\mathrm{N}$-urea in each experimental plots was performed manually, simulating the LEPA sprinkler to distribute the solution over the coffee canopy. N-urea was applied every 15 days, starting on August 1st 2008 and ending on July 17 th 2009.

Experimental plots were composed of three central plants with four bordering plants on each side. The experimental setup was completely randomized with five treatments and four replications. The treatments corresponded to the following rates of $\mathrm{N}$ : $\mathrm{T} 0$, no $\mathrm{N}$ application; T1-200 kg ha ${ }^{-1} \mathrm{~N}\left(38 \mathrm{~g} \mathrm{plant}^{-1} \mathrm{~N} ; 84 \mathrm{~g}\right.$ plant $^{-1}$ urea); T2-400 kg ha ${ }^{-1} \mathrm{~N}\left(76 \mathrm{~g} \mathrm{plant}^{-1} \mathrm{~N}\right.$; $164 \mathrm{~g} \mathrm{plant}^{-1}$ urea); T3-600 kg ha ${ }^{-1}$ (114 $\mathrm{g} \mathrm{plant}^{-1}$ $\mathrm{N} ; 253 \mathrm{~g} \mathrm{plant}^{-1}$ urea); and T4-800 kg ha ${ }^{-1}$ (152 g plant $^{-1} \mathrm{~N} ; 338$ g plant $^{-1}$ urea). The experimental field received $380 \mathrm{~kg} \mathrm{ha}^{-1}$ potassium $(\mathrm{K}), 2.4 \mathrm{~kg} \mathrm{ha}^{-1}$ zinc (Zn), $6.7 \mathrm{~kg} \mathrm{ha}^{-1}$ boron (B), $9.8 \mathrm{~kg} \mathrm{ha}^{-1}$ manganese $(\mathrm{Mn})$, and $0.6 \mathrm{~kg} \mathrm{ha}^{-1}$ copper $(\mathrm{Cu})$, supplied from September 2008 to June 2009 by fertigation.

Samples to evaluate the $\mathrm{N}$ assimilation enzymes and $\mathrm{N}$ nutritional status were obtained during the phenological phases, with a total of six samplings at: vegetative phase (VG), 56 days before anthesis $(-56)$; anthesis (A) (0); pinhead drop (PD) (42 days after anthesis, DAA); rapid expansion (RE) and grain filling (GF) (126-168 DAA); and maturation (MA) (266 DAA). Leaves of the third pair collected at the midpoint of the canopy (collected for nutrient status diagnosis) were stored on ice and immediately transported to the laboratory for enzymatic assays and analyses of amino acids, $\mathrm{N}$, nitrate and ammonium.

\subsection{Nitrate reductase activity}

The in vivo nitrate reductase activity was determined according to the procedure of Radin (1974). Leaf samples were collected at 12:00 pm. Freshly collected leaf tissue was stored in plastic bags, transported to the laboratory on ice, and rinsed with deionized water. Afterwards, $100 \mathrm{mg}$ of fresh tissue cut in discs was transferred to assay tubes containing $5 \mathrm{~mL}$ of phosphate buffer solution pH 7.4 (50 mM Na-phosphate buffer $+200 \mathrm{mM} \mathrm{KNO}_{3}$ ). Thereafter, the assay tubes (wrapped in aluminum foil to protect from the light) were incubated in a $37{ }^{\circ} \mathrm{C}$ water bath for $30 \mathrm{~min}$. The reaction was stopped by adding $1 \mathrm{~mL}$ of $1 \%$ sulfanilamide in $2 \mathrm{M} \mathrm{HCl}$ followed by $1 \mathrm{~mL}$ of $0.05 \%$ naphtylenediamine solution. The nitrite $\left(\mathrm{NO}_{2}{ }^{-}\right)$produced was measured in a spectrophotometer at $540 \mathrm{~nm}$, using a nitrite standard calibration curve. 
The enzyme activity was directly related to the amount of $\mathrm{NO}_{2}^{-}$and the results were expressed in $\mu \mathrm{mol}$ $\mathrm{NO}_{2}{ }^{-} \mathrm{g}^{-1} \mathrm{~h}^{-1} \mathrm{FW}$ (fresh weight).

\subsection{Glutamine synthetase activity}

Leaves were initially frozen with liquid $\mathrm{N}_{2}$. Before tissue maceration, a $2.0 \mathrm{~mL}$ aliquot of the extract buffer (200 mM Tris-HCl, pH 7.5) was added and the material was homogenized and further centrifuged at $3.248 \times g$ for $5 \mathrm{~min}$ at $4{ }^{\circ} \mathrm{C}$. The supernatant was reserved for the enzyme activity.

Glutamine synthetase activity was measured by the method proposed by Elliott (1953), which is based on the enzyme biosynthetic activity in the formation of $\lambda$ glutamyl hydroxamate. This reaction was carried out in assay tubes under continuous shaking in a water bath at $30{ }^{\circ} \mathrm{C}$, with the addition of: $0.25 \mathrm{~mL}$ extraction buffer solution; $0.1 \mathrm{~mL} 50 \mathrm{mM}$ ATP, $\mathrm{pH} 7.0 ; 0.25 \mathrm{~mL}$ $500 \mathrm{mM}$ sodium glutamate; $0.05 \mathrm{~mL} 1 \mathrm{M} \mathrm{MgSO}_{4}$; $0.05 \mathrm{~mL} 100 \mathrm{mM}$ cysteine; $0.15 \mathrm{~mL} 100 \mathrm{mM}$ hydroxylamine, $\mathrm{pH} 7.0$; and $0.15 \mathrm{~mL}$ of the crude extract supernatant. After intervals of incubation, the reaction was stopped by the addition of $1 \mathrm{~mL}$ of a 1:1:1 mixture of $10 \% \mathrm{FeCl}_{3}: 24 \%$ (w/v) TCA: $6 \mathrm{M} \mathrm{HCL}$, leading to the formation of a brown-yellowish precipitate. Thereafter, the mixture was centrifuged at $3.248 \times g$ and the supernatant color was analyzed in a spectrophotometer at $540 \mathrm{~nm}$ to determine the formation of $\lambda$-glutamyl hydroxamate $(\lambda-\mathrm{GH})$, using a standard calibration curve. GS specific activity was expressed as $\mu \mathrm{mol} \lambda$-GH h $\mathrm{h}^{-1} \mathrm{mg}^{-1}$ protein.

The total soluble protein concentration was determined according to the Bradford (1976) procedure, using tissue extracts prepared with Tris-buffer (200 mM Tris-HCl, pH 7.5). To a $100 \mu \mathrm{L}$ aliquot extract sample $5 \mathrm{~mL}$ Bradford reagent was added and the absorbance was read at $595 \mathrm{~nm}$. Total soluble protein concentrations was calculated using by referring to a bovine serum albumin (BSA) standard calibration curve. The results were expressed in $\mathrm{mg} \mathrm{g}^{-1}$ fresh tissue.

\subsection{Urease activity}

Urease activity was measured according to the whole tissue method described by Hogan et al. (1983), with ammonium determination as suggested by McCullough (1967). One hundred mg fresh tissue cut in discs was transferred to assay tubes containing $8 \mathrm{~mL} 50 \mathrm{mM}$ phosphate buffer ( $\mathrm{pH} 7.4) 0.2 \mathrm{M}$ urea and $0.6 \mathrm{M} \mathrm{n}$-propanol for a period of $3 \mathrm{~h}$. After incubation, an aliquot of $0.5 \mathrm{~mL}$ supernatant was added to $2.5 \mathrm{~mL}$ Reagent I $(0.1 \mathrm{M}$ phenol and $170 \mu \mathrm{M}$ sodium nitroprusside). Afterwards, $2.5 \mathrm{~mL}$ Reagent II $\left(0.125 \mathrm{M} \quad \mathrm{NaOH}+0.15 \mathrm{M} \quad \mathrm{Na}_{2} \mathrm{HPO}_{4} .12 \mathrm{H}_{2} \mathrm{O}\right.$ $+\mathrm{NaOCl}\left(3 \% \mathrm{Cl}_{2}\right)$ was added for determination of ammonium. This reaction was carried out in capped assay tubes under continuous shaking in a water bath at $37{ }^{\circ} \mathrm{C}$ for $35 \mathrm{~min}$. Ammonium was measured in a spectrophotometer at $625 \mathrm{~nm}$, using a $\mathrm{NH}_{4} \mathrm{Cl}$ standard calibration curve and urease activity was expressed as $\mu \mathrm{mol} \mathrm{N}-\mathrm{NH}_{4}{ }^{+} \mathrm{h}^{-1} \mathrm{~g}^{-1} \mathrm{FW}$.

\subsection{Amino acids}

Amino acids were extracted from lyophilizated leaves $(\sim 0.2 \mathrm{~g})$ with methanol:chloroform:water (12:5:3, v/v/v) (Bielesky and Turner 1966; Andrade et al. 2010). Amino acid concentrations were quantitatively estimated using a ninhydrin reagent (Cocking and Yemm 1954) using a leucine standard calibration curve.

\subsection{Total nitrogen, nitrate and ammonium determination}

Coffee leaf samples were dried in a forced-air oven at $65{ }^{\circ} \mathrm{C}, 72 \mathrm{~h}$ and ground with a mortar and pestle. Total-N was determined by the Kjeldahl method (Bremer 1965). The concentrations of nitrate and ammonium in plant tissues were determined using a $1 \mathrm{M} \mathrm{KCl}$ solution as described by Tedesco and Gianello (1979).

\subsection{Statistical analysis}

Statistical analyses were performed using the Statistical Analysis System (SAS) software for Windows 6.11 (SAS 1996). Variance analysis (F-test) was employed to evaluate the significance of the treatments. Pearson correlation among N-rate, leaf N, $\mathrm{NH}_{4}{ }^{+}, \mathrm{NO}_{3}{ }^{-}$, glutamine synthetase, nitrate reductase, urease and amino acids were obtained and tested by the CORR procedure of SAS. Graphs were made with the SigmaPlot ${ }^{\circledR}$ software. 


\section{Results}

Maximum, minimum and average air temperature and precipitation from August 2008 to July 2009 are shown in Fig. 1. Minimum air temperature start to increase by early August and precipitation by November. This period showed the lowest thermal amplitudes and the highest minimum temperatures.

During the annual reproductive cycle, coffee plants usually exhibit changes in nitrate uptake and assimilation capacity, which have been associated with the various physiological developmental stages of flowers and fruits. Figure $2 \mathrm{a}-\mathrm{d}$ show the changes of $\mathrm{N}$ nutritional status (nitrogen, amino acids, nitrate, and ammonium content) of coffee plants during phenological development stages. Leaf-N and amino acids

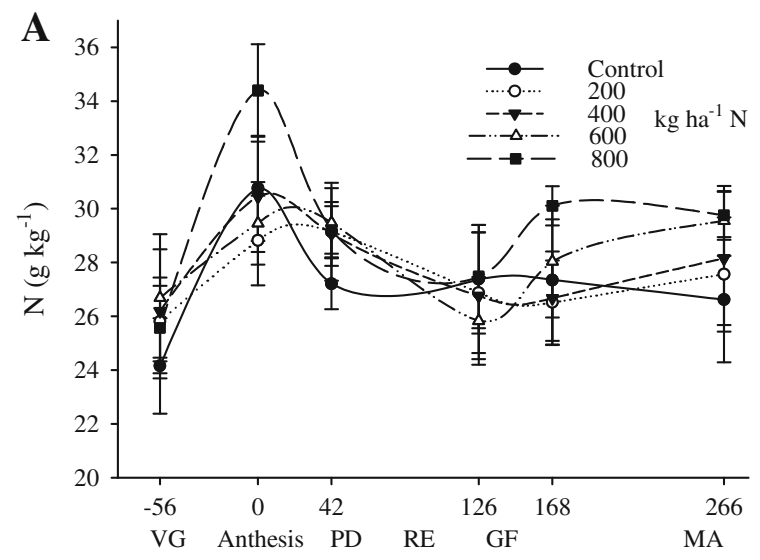

Days before and after anthesis

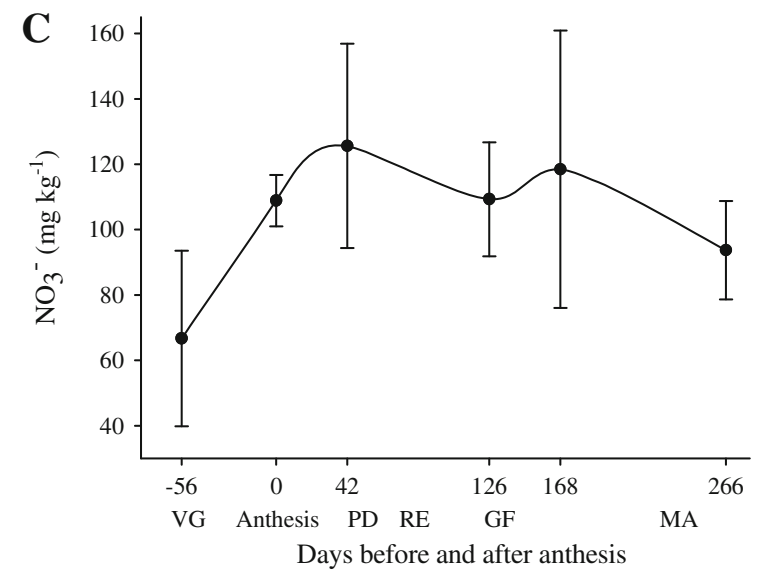

Fig. 2 Nitrogen (a), amino acids (b), nitrate (c), and ammonium content (d) in Coffea arabica leaves during grain development (vegetative phase (VG), anthesis, pinhead drop concentration increased in coffee phenological phase during anthesis stage but slowed down through pinhead stage. However, nitrate content increased on anthesis until maturation stage (Fig. 2c) and ammonium increased on pinhead and grain filling stage (Fig. 2d).

Figure $3 \mathrm{a}-\mathrm{c}$ show the activities of $\mathrm{N}$ assimilation enzymes during the flower and grain development stages in response to $\mathrm{N}$-urea supply by fertigation. High nitrate reductase enzyme activities were observed during pre-anthesis (VG) probably due to the beginning of rainfall season and concomitant temperature increase, which leads to the increase of $\mathrm{NO}_{3}{ }^{-}$uptake. GS highest activity was achieved during rapid expansion stage and urease activity late on grain fillign phase.

Correlation among $\mathrm{N}$ rates and all variables analyzed during phenological phase (vegetative,
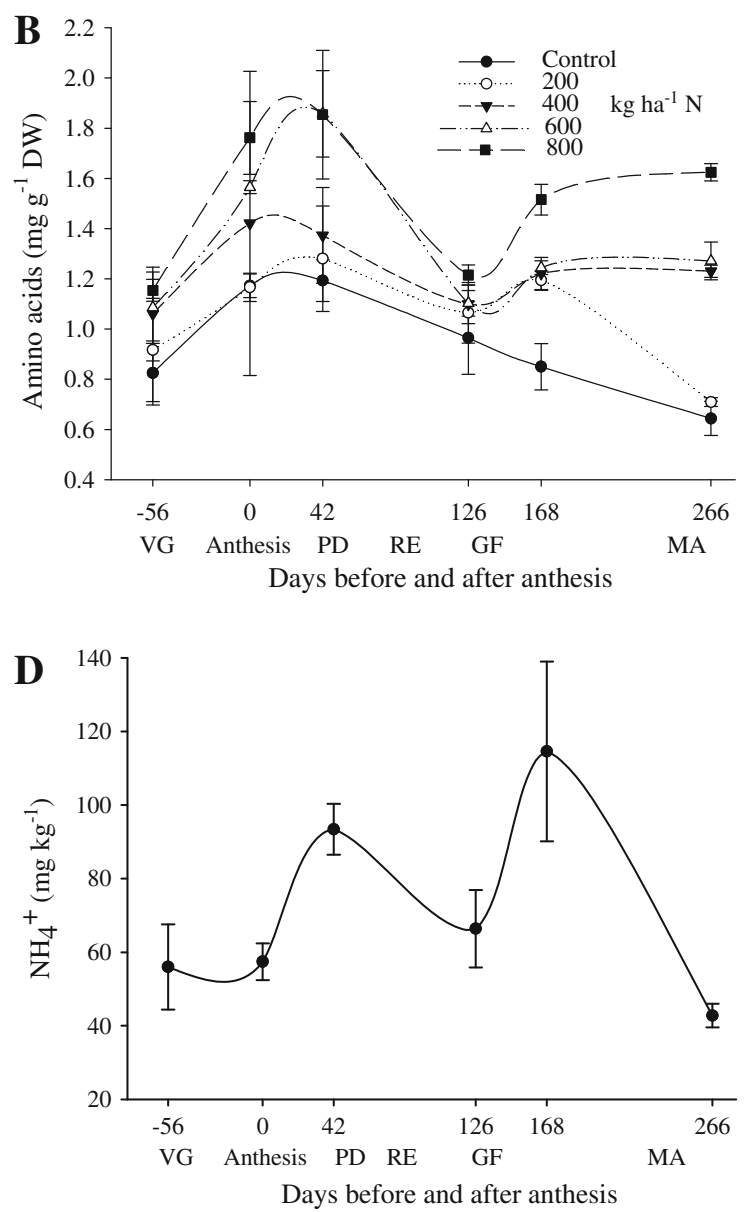

(PD), rapid grain expansion (RE), grain filling (GF), maturation (MA)) due to $\mathrm{N}$ fertilization by fertigation. Error bars represent standard deviation (SD) 

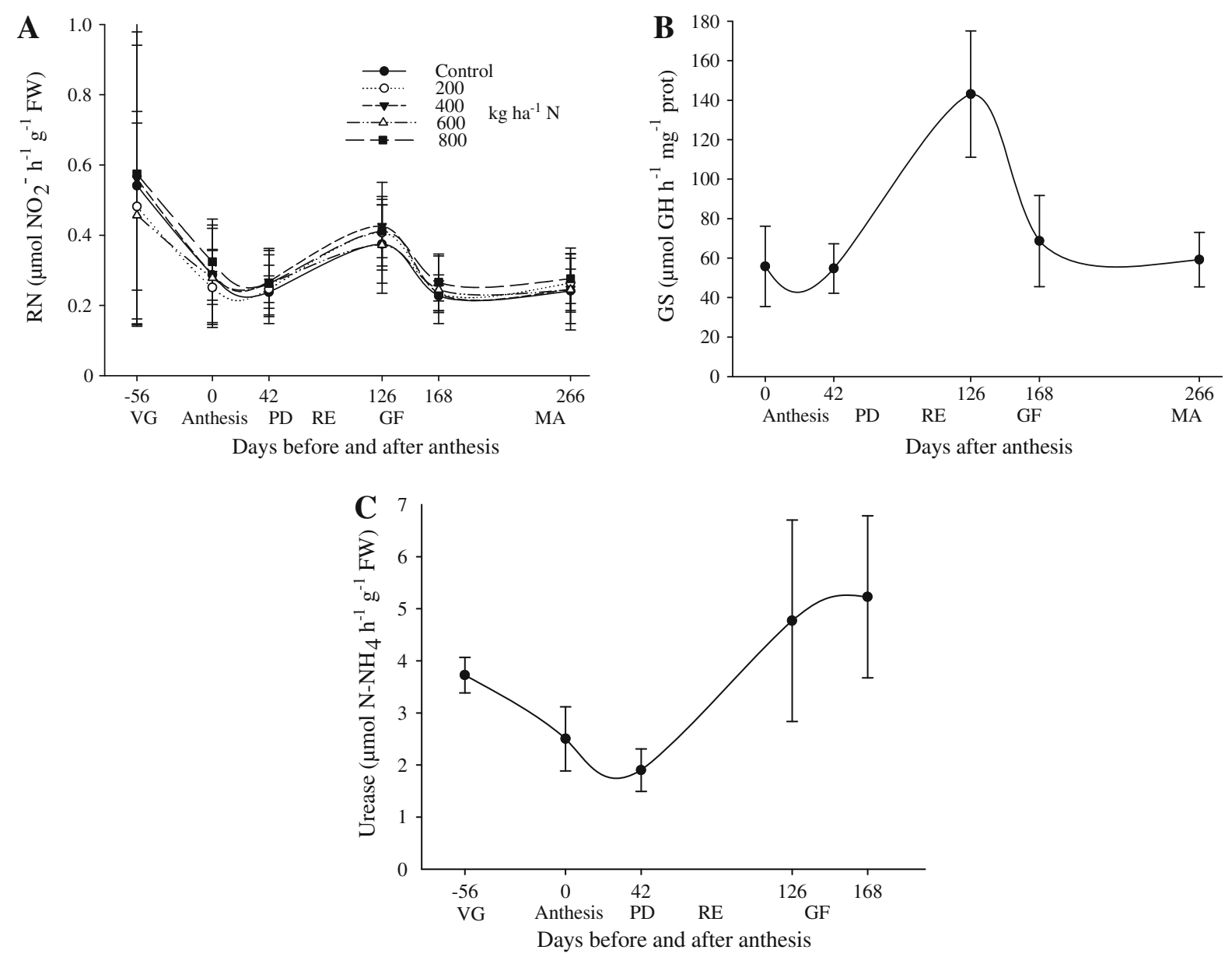

Fig. 3 Nitrate reductase (a), glutamine synthetase (b), and urease activity (c) in Coffea arabica leaves during grain development (vegetative phase (VG), anthesis, pinhead drop

anthesis, pinhead drop, rapid expansion, grain filling and maturation stages) are presented in Table 1. Correlation was found between $\mathrm{N}$ rates and amino acids at all phenological phase evaluated $(P<0.01)$.

There was a significant interaction between $\mathrm{N}$ rates and phenological phase of coffee plants for leaf-N, amino acids, $\mathrm{NO}_{3}{ }^{-}$and GS activity. $\mathrm{NH}_{4}{ }^{+}$and $\mathrm{RN}$ did not vary with $\mathrm{N}$ rate, although they changed during phenological phase (Table 2).

\section{Discussion}

The first application of $\mathrm{N}$ in the fertigation system of coffee trees was during vegetative stage (56 days before anthesis) when leaves showed low levels of $\mathrm{N}$
(PD), rapid grain expansion (RE), grain filling (GF), maturation (MA)) due to $\mathrm{N}$ fertilization by fertigation. Error bars represent standard deviation (SD)

(25.7 $\left.\mathrm{g} \mathrm{kg}^{-1} \mathrm{DW}\right)$ and amino acids (1.01 $\left.\mathrm{mg} \mathrm{g}^{-1} \mathrm{DW}\right)$ (Fig. 2a, b) due to strong remobilization of nitrogen compounds to the fruit during the previous reproductive phase. From the vegetative stage to anthesis $\mathrm{N}$ and amino acid contents in the leaves increased in all treatments, including the control plants. This increase in $\mathrm{N}$ accumulation by plants coincided with the start of the rainy season and its increased temperature. These are factors which favor greater release of $\mathrm{N}$ in the soil, and the re-use of nitrogen accumulated over the winter in the reserve organs (DaMatta et al. 1999; Amaral et al. 2001).

The increase in the $\mathrm{N}$ concentration during anthesis was partly due to the effect of $\mathrm{N}$ fertilization, started 70 days before the evaluation. In addition, the greatest temperature and water availability occurred in this 
Table 1 Pearson correlation for N-rate, leaf $\mathrm{N}, \mathrm{NH}_{4}{ }^{+}, \mathrm{NO}_{3}{ }^{-}$, glutamine synthetase (GS), nitrate reductase (NR), urease and amino acids (AA) during phenological phase: vegetative phase (VG), anthesis, pinhead drop (PD), rapid grain expansion (RE), grain filling (GF), maturation (MA)

\begin{tabular}{|c|c|c|c|c|c|c|c|}
\hline & $\mathrm{N}$ & $\mathrm{NH}_{4}^{+}$ & $\mathrm{NO}_{3}^{-}$ & GS & NR & Urease & AA \\
\hline \multicolumn{8}{|c|}{ Vegetative phase (56 days before anthesis) } \\
\hline Rate & ns & ns & ns & ns & ns & ns & $0.65 * *$ \\
\hline $\mathrm{N}$ & & ns & ns & ns & ns & ns & ns \\
\hline $\mathrm{NH}_{4}^{+}$ & & & ns & ns & ns & ns & ns \\
\hline $\mathrm{NO}_{3}^{-}$ & & & & $\mathrm{ns}$ & ns & ns & $\mathrm{ns}$ \\
\hline GS & & & & & ns & ns & ns \\
\hline NR & & & & & & ns & ns \\
\hline Urease & & & & & & & ns \\
\hline \multicolumn{8}{|c|}{ Anthesis (0 day) } \\
\hline Rate & $0.56 * *$ & ns & ns & ns & ns & ns & $0.67 * *$ \\
\hline $\mathrm{N}$ & & ns & ns & ns & ns & ns & $0.48 *$ \\
\hline $\mathrm{NH}_{4}^{+}$ & & & ns & ns & ns & ns & $\mathrm{ns}$ \\
\hline $\mathrm{NO}_{3}^{-}$ & & & & ns & ns & ns & ns \\
\hline GS & & & & & $-0.43 *$ & $\mathrm{~ns}$ & ns \\
\hline NR & & & & & & ns & ns \\
\hline Urease & & & & & & & $\mathrm{ns}$ \\
\hline \multicolumn{8}{|c|}{ Pinhead drop (42 days after anthesis) } \\
\hline Rate & $0.45 *$ & ns & ns & $-0.53 * *$ & ns & ns & $0.81 * *$ \\
\hline $\mathrm{N}$ & & ns & ns & ns & ns & ns & $0.44 *$ \\
\hline $\mathrm{NH}_{4}^{+}$ & & & ns & ns & ns & ns & ns \\
\hline $\mathrm{NO}_{3}^{-}$ & & & & $\mathrm{ns}$ & ns & $\mathrm{ns}$ & $\mathrm{ns}$ \\
\hline GS & & & & & ns & $\mathrm{ns}$ & $-0.55 * *$ \\
\hline NR & & & & & & ns & $\mathrm{ns}$ \\
\hline Urease & & & & & & & ns \\
\hline \multicolumn{8}{|c|}{ Rapid expansion (126 days after anthesis) } \\
\hline Rate & ns & $0.42 *$ & ns & ns & ns & ns & $0.67 * *$ \\
\hline $\mathrm{N}$ & & ns & ns & ns & ns & ns & ns \\
\hline $\mathrm{NH}_{4}^{+}$ & & & ns & ns & ns & ns & ns \\
\hline $\mathrm{NO}_{3}^{-}$ & & & & ns & ns & $\mathrm{ns}$ & $\mathrm{ns}$ \\
\hline GS & & & & & $0.40 *$ & ns & ns \\
\hline $\mathrm{RN}$ & & & & & & $0.49 *$ & ns \\
\hline Urease & & & & & & & ns \\
\hline \multicolumn{8}{|c|}{ Grain filling (168 days after anthesis) } \\
\hline Rate & $0.5^{*}$ & $0.38 *$ & $\mathrm{~ns}$ & ns & ns & ns & $0.89 * *$ \\
\hline $\mathrm{N}$ & & ns & ns & $0.56 * *$ & $0.54 * *$ & ns & $0.48 * *$ \\
\hline $\mathrm{NH}_{4}^{+}$ & & & ns & ns & ns & ns & ns \\
\hline $\mathrm{NO}_{3}^{-}$ & & & & ns & ns & ns & ns \\
\hline GS & & & & & ns & ns & ns \\
\hline NR & & & & & & ns & ns \\
\hline Urease & & & & & & & ns \\
\hline \multicolumn{8}{|c|}{ Maturation (266 days after anthesis) } \\
\hline Rate & $0.57 * *$ & ns & ns & $-0.76^{* *}$ & ns & ns & $0.96 * *$ \\
\hline $\mathrm{N}$ & & ns & ns & $0.54 * *$ & ns & ns & $0.52 * *$ \\
\hline
\end{tabular}


Table 1 continued

\begin{tabular}{|c|c|c|c|c|c|c|c|}
\hline & $\mathrm{N}$ & $\mathrm{NH}_{4}{ }^{+}$ & $\mathrm{NO}_{3}{ }^{-}$ & GS & NR & Urease & AA \\
\hline $\mathrm{NH}_{4}^{+}$ & & & $\mathrm{ns}$ & ns & $-0.40^{*}$ & $\mathrm{~ns}$ & $\mathrm{~ns}$ \\
\hline $\mathrm{NO}_{3}{ }^{-}$ & & & & ns & ns & ns & ns \\
\hline GS & & & & & $\mathrm{ns}$ & ns & $-0.67 * *$ \\
\hline NR & & & & & & ns & ns \\
\hline Urease & & & & & & & ns \\
\hline
\end{tabular}

$n s$ Non-significant

$* *$ and * Significant at 0.01 and 0.05 levels respectively

Table 2 Summary of statistical analyses for rate, phenology, and interaction between $\mathrm{N}$ rate and phenology

\begin{tabular}{lccc}
\hline Variable & N rate & Phenology & N rate vs phenology \\
\hline Leaf-N & $0.0250^{*}$ & $<0.0001^{*}$ & $0.0446^{*}$ \\
Amino acids & $<0.0001^{*}$ & $<0.0001^{*}$ & $<0.0001^{*}$ \\
$\mathrm{NO}_{3}{ }^{-}$ & 0.4904 & $<0.0001^{*}$ & $<0.0001^{*}$ \\
$\mathrm{NH}_{4}{ }^{+}$ & 0.1414 & $<0.0001^{*}$ & 0.2248 \\
$\mathrm{RN}^{\mathrm{GS}}$ & 0.0110 & $<0.0001^{*}$ & 0.2320 \\
Urease & 0.1007 & $<0.0001^{*}$ & $0.0017^{*}$ \\
\hline
\end{tabular}

* Significant at $5 \%$ level by F-test $(p<0.05)$

phase (Fig. 1). Part of the $\mathrm{N}$ also may have come from the mineralization of the $\mathrm{N}$ present in the soil, suggested by the increased $\mathrm{N}$ concentration even before this nutrient was applied (Neto et al. 2011). Another explanation for the increased $\mathrm{N}$ concentration during anthesis can be redistribution of nitrogenated compounds from other organs, such as roots, stem, and branches, which store compounds in the winter that are redistributed at the start of the rainy season (Reis et al. 2009, 2011).

At anthesis, $34.4 \mathrm{~g} \mathrm{~kg}^{-1}$ (DW) leaf $\mathrm{N}$ was observed with application of $800 \mathrm{~kg} \mathrm{ha}^{-1} \mathrm{~N}$-urea, while amino acids increased gradually as the $\mathrm{N}$-rate increased, from the anthesis to the pinhead drop phase (PD). Then, after anthesis, $\mathrm{N}$ and amino acid contents in the leaves decreased progressively until grain filling phase (GF) when an increase was observed in the 400, 600 and $800 \mathrm{~kg} \mathrm{ha}^{-1}$ treatments. This drop in the GF phase is probably due to $\mathrm{N}$ remobilization from the leaves to the developing beans (Rena et al. 2001; Reis et al. 2011). Nitrate content in the leaves showed a twofold increase at the beginning of the fertigation and remained constant during fruit development (Fig. 2c). However, ammonia content showed a bimodal curve with two peaks, the first at PD phase and the second at GF phase. Taken together, N, amino acid, nitrate and ammonium contents showed similar variation curves, with a decrease in the GF phase, that indicates the high demand by nitrogen compounds for the formation of the coffee fruit (Rena et al. 2001): $\mathrm{N}$ is the second nutrient most demanded by grains and even applications of the order of $800 \mathrm{~kg} \mathrm{~N}^{-1}$ does not prevent this reduction of nitrogen leaf (Fig. 2a).

Regarding the uptake of nitrogen forms by coffee plants, Mazzafera and Gonçalves (1999) stated that $52 \%$ of the $\mathrm{N}$ present in the xylem of coffee was $\mathrm{NO}_{3}{ }^{-}$, which is rapidly incorporated by the nitrate reductase. Similarly, Carelli et al. (1989) found that leaf nitrate reductase activity in coffee plants growing under natural light-temperature regimes, showed higher values prior to anthesis and at the end of fruit development. Such results indicate that the differential nitrate uptake, associated with the phenological phases, might be an important factor in the control of leaf nitrate reductase during the annual cycle of the mature coffee plant. This is independent of the variations promoted by seasonal environmental conditions (Carelli et al. 2006; Reis et al. 2007).

In Costa Rica, Carvajal et al. (1969) and in Brazil, Reis et al. (2009) observed that nitrate uptake rates of mature coffee plants were higher before anthesis and at the beginning of fruit maturation. Glutamine synthetase and urease activity did not change as a function of N-urea application, but only with phenological phases. On the other hand, $\mathrm{NH}_{4}{ }^{+}$was not detected in xylem even when $\mathrm{NH}_{4}{ }^{+}$was present in solution. Although urea transporters are identified in plants (Witte 2011), there is still no information on the conditions under which plants can take up urea from the soil. In this work the urease activity varied only in phenological phase and not with the $\mathrm{N}$-urea applied. 
The highest glutamine synthetase activity in the leaves was observed during the rapid expansion (RE) of grains (Fig. 2c). In all other stages the activity remained at similar levels and three times lower than the peak observed at RE stage. Glutamine synthetase is responsible for re-assimilation of $\mathrm{NH}_{4}{ }^{+}$from photorespiration, proteolysis and amino acid catabolism during mobilization of $\mathrm{N}$ for translocation and/or storage in senescent tissues (Lea et al. 1990; Kamachi et al. 1991), which may explain the increased levels of amino acids and nitrogen in plants after the period of highest enzyme activity. A previous report showed intense amino acid mobilization during coffee grain endosperm formation (Reis et al. 2009). Furthermore, the glutamine synthetase activity in coffee plants shows no response to high $\mathrm{N}$ application rates by fertigation (Table 1). These results might indicate that glutamine synthetase activity in coffee also represents the rate-limiting step in $\mathrm{N}$ assimilation.

The peak of urease activity in coffee leaves was observed at 126 days after anthesis (rapid grain expansion stage). Urease is known to catalyze urea assimilation after uptake into plant cells, which hydrolyze urea in the cytosol to $\mathrm{CO}_{2}$ and ammonia. Ammonia or ammonium is subsequently fixed by glutamine synthetase. Curiously, the highest urease activity coincides with the peak of glutamine synthetase during rapid grain expansion (126 days after anthesis). Reis et al. (2009) observed the nickel concentration in coffee leaves increase during grain development stage. Urease is a nickel-dependent enzyme that could play an important role in optimal $\mathrm{N}$-use efficiency by recycling urea-N generated from arginase action on arginine (Polacco et al. 2013). Urea metabolism in coffee plants is still not well understood. In addition, the effects of long-term assessment of $\mathrm{N}$ assimilation enzymes, nutritional status of perennial crops, and monitoring soil properties upon urea application in agricultural are still somewhat unclear and further investigation is required.

Nitrogen metabolism enzymes showed higher values during anthesis and grain development stages. We argue that this is because the evaluation periods are coincident with the periods of intense metabolism and nutrient demand from the sinks (flowers and fruits). The first is the late phase of flower development (Carelli et al. 1989), when the flower buds rapidly expand and show a sharp increase in dry matter, requiring rapid metabolite transport from the nearest photosynthesizing leaves (Barros et al. 1982). The second is the late phase of fruit development, during formation of seed endosperms, which are powerful sinks of carbohydrates and minerals (Canell 1975). Higher $\mathrm{N}$ requirement during the formation of the fruit is because it consists of a repository of amino acids and proteins. The increase of $\mathrm{N}$ fertilization rates by fertigation increased coffee yield, which ranged from 2,340 to $4,320 \mathrm{~kg} \mathrm{ha}^{-1}$ when applied to $400 \mathrm{~kg} \mathrm{ha}^{-1}$ of N. The yield corresponding to $90 \%$ of the relative production in response to $\mathrm{N}$ rates was obtained with the application of $415 \mathrm{~kg} \mathrm{ha}^{-1} \mathrm{~N}$ (Neto et al. 2011).

The results of the present study suggest that both $\mathrm{N}$ metabolism enzymes, and the content of nitrate and ammonium in coffee were directly related to the phenological cycle. The $\mathrm{N}$ fertigation rates are correlated with the $\mathrm{N}$ and amino acid content (Table 1). The nitrate reductase and urease showed highest activities before anthesis, and during grain filling. Glutamine synthetase showed highest activities during rapid grain expansion. The data also indicate that there is merit in gaining greater understanding of $\mathrm{N}$ metabolism in coffee plants grown under high-intensive systems. There is therefore merit in conducting further research on how monitoring the $\mathrm{N}$ assimilation enzymes might be used to improve fertilizer management of coffee in commercial orchards.

Acknowledgments The authors want to thank Dr. Joe C. Polacco who revised the English translation. Authors also thanks the Conselho Nacional de Desenvolvimento Científico and Tecnológico (CNPq-Brazil) (A.P. Neto and J.L. Favarin) and Fundação de Amparo à Pesquisa do Estado de São Paulo (FAPESP) (T. Tezotto) for fellowships granted.

\section{References}

Amaral JAT, DaMatta FM, Rena AB (2001) Effects of fruiting on the growth of arabica coffee trees as related to carbohydrate and nitrogen status and to nitrate reductase activity. Braz J Plant Physiol 13:66-74

Andrade SAL, Gratão PL, Azevedo RA, Silveira APD, Schiavinato MA, Mazzafera P (2010) Biochemical and physiological changes in jack bean under mycorrhizal symbiosis growing in soil with increasing $\mathrm{Cu}$ concentrations. Environ Exp Bot 68:198-207

Barros RS, Maestri M, Moreira RC (1982) Sources of assimilates for expanding flower buds of coffee. Turrialba 32:371-377

Bielesky RL, Turner NA (1966) Separation and estimation of aminoacid in crude plant extracts by thin-layer electrophoresis and chromatography. Anal Biochem 17:278-293 
Bradford MM (1976) A rapid sensitive method for the quantitation of microgram quantities of protein utilizing the principle of protein-dye-binding. Anal Biochem 72:248-254

Bremer JM (1965) Total nitrogen. In: Black CA (ed) Methods of soil analysis, Part 2. American Society of Agronomy, Madison, pp 1149-1178

Canell MGR (1975) Crop physiological aspects of coffee bean yield: a review. J Coffee Res 5:7-20

Carelli MLC, Fahl JI, Magalhaes AC (1989) Nitrate assimilation in coffee plants during reproductive development. Rev Bras Ciênc Solo 13:59-64

Carelli ML, Fahl JI, Ramalho JC (2006) Aspects of nitrogen metabolism in coffee plants. Braz J Plant Phys 18(1):9-21

Carvajal JF, Acevedo A, Lopez CA (1969) Nutrient uptake by coffee tree during a yearly cycle. Turrialba 19:13-20

Cocking EC, Yemm EW (1954) Estimation of amino acids by ninhydrin. Biochem J 58:7-8

CONAB (2010) Monitoring of the Brazilian coffee production of 2009. Companhia Nacional de Abastecimento, Brasília

DaMatta FM, Amaral JAT, Rena AB (1999) Growth periodicity in trees of Coffea arabica $\mathrm{L}$. in relation to nitrogen supply and nitrate reductase activity. Field Crop Res 60:223-229

Elliott WH (1953) Isolation of glutamine synthetase and glutamotransferase from green peas. $\mathrm{J}$ Biol Chem 201:661-672

Fenilli TAB, Reichardt K, Dourado Neto D, Trivelin PCO, Favarin JL, Costa F, Bacchi OS (2007) Growth, development and fertilizer $\mathrm{N}$ recovery for a coffee crop growing in Brazil. Sci Agric 64:541-547

Hogan ME, Swift IE, Done J (1983) Urease assay and ammonia release from leaf tissue. Phytochemistry 22:663-665

Kamachi K, Yamaya T, Mae T, Ojima K (1991) A role for glutamine synthetase in the remobilization of leaf nitrogen during natural senescence in rice leaves. Plant Physiol 96:411-417

Lea PJ, Blackwell RD, Chen F-L, Hecht U (1990) The enzymes of ammonia assimilation. Methods Plant Biochem 3:129-144

Malavolta E, Nogueira NL, Heinrichs R, Higashi EN, Rodriguez-Peres VJ, Guerra E, Oliveira SC, Cabral CP (2004) Evaluation of the nutritional status of the cotton plant (Gossypium hirsutum L.) with respect to nitrogen. Commun Soil Sci Plant 35:1007-1019

Matějková Š, Kumhálová J, Lipavský J (2010) Evaluation of crop yield under different nitrogen doses of mineral fertilization. Plant Soil Environ 56:163-167

Matson PA, Naylor R, Ortiz-Monasterio I (1998) Integration of environmental, agronomic, and economic aspects of fertilizer management. Science 280:1-8

Mazzafera P, Gonçalves KV (1999) Nitrogen compounds in the xylem sap of coffee. Phytochemistry 50:383-386

McCullough H (1967) The determination of ammonia in whole blood by a direct colorimetric method. Clin Chim Acta 17:297-304
Neto AP, Favarin JL, Almeida REM, Dias CTS, Tezotto T, Alves ALG, Moraes MF (2011) Changes of nutritional status during a phenological cycle of coffee under high nitrogen supply by fertigation. Commun Soil Sci Plant 42:2414-2425

Panek JA, Matson PA, Ortiz-Monasterio I, Books P (2000) Distinguishing nitrification and denitrification sources of $\mathrm{N}_{2} \mathrm{O}$ in a Mexican wheat system using ${ }^{15} \mathrm{~N}$. Ecol Appl 10:506-514

Peoples MB, Herridgee DF, Ladha JK (1995) Biological nitrogen fixation: an efficient source of nitrogen for sustainable agricultural production? Plant Soil 174:3-28

Polacco JC, Krueger RW, Winkler RG (1985) Structure and possible ureide degrading function of the ubiquitous urease of soybean. Plant Physiol 79:794-800

Polacco JC, Mazzafera P, Tezotto T (2013) Opinion-Nickel and urease in plants: still many knowledge gaps. Plant Sci 199-200:79-90

Radin JW (1974) Distribution and development of nitrate reductase activity in germinating cotton seedlings. Plant Physiol 53:458-463

Reis AR, Furlani Jr. E, Haga KW (2007) Nitrate reductase activity in coffee leaves in relation to nitrogen supply. Acta Sci Agron 29:269-276

Reis AR, Favarin JL, Gallo LA, Malavolta E, Moraes MF, Lavres Jr. J (2009) Nitrate reductase and glutamine synthetase activity in coffee leaves during fruit development. Rev Bras Ciênc Solo 33:315-324

Reis AR, Favarin JL, Gallo LA, Moraes MM, Tezotto T, Lavres Junior J (2011) Influence of nitrogen fertilization on nickel accumulation and chemical composition of coffee plants during fruit development. J Plant Nutr 34:1853-1866

Rena AB, Barros RS, Maestri M (2001) Reproductive development of coffee. In: Zambolim L (ed) Technology of production of quality coffee. Department of Plant Pathology, Viçosa, pp 101-128

SAS (1996) SAS/STAT user's guide, version 6.11, 4th. Statistical Analysis System Institute, Cary

Sirko A, Brodzik R (2000) Plant ureases: roles and regulation. Acta Biochim Pol 47:1189-1195

Tedesco MJ, Gianello C (1979) Take-appart Kjeldahl glass unit for steam distillation on ammonia. Rev Bras Ciênc Solo 3:61-63

van Raij B, Cantarella H, Quaggio JA, Furlani MAC (1996) Recomendações de adubação e calagem para o Estado de São Paulo, 2nd edn. Instituto Agronômico \& Fundação IAC, Campinas (Boletim Técnico, 100)

Witte CP (2011) Urea metabolism in plants. Plant Sci 180:431-438

Wray JL, Fido RJ (1990) Nitrate reductase and nitrite reductase. In: Dey PM, Harborne JB (eds) Methods in plant biochemistry, vol 3. Academic Press, Waltham, pp 241-256 